Newfoundland and Labrador Studies

\title{
Jennifer Bowering Delisle. The Newfoundland Diaspora: Mapping the Literature of Outmigration.
}

\section{Caitlin Charman}

Volume 29, Number 1, Spring 2014

URI: https://id.erudit.org/iderudit/1062248ar

DOI: https://doi.org/10.7202/1062248ar

See table of contents

Publisher(s)

Faculty of Arts, Memorial University

\section{ISSN}

1719-1726 (print)

1715-1430 (digital)

Explore this journal

Cite this review

Charman, C. (2014). Review of [Jennifer Bowering Delisle. The Newfoundland Diaspora: Mapping the Literature of Outmigration.] Newfoundland and Labrador Studies, 29(1). https://doi.org/10.7202/1062248ar viewed online.

https://apropos.erudit.org/en/users/policy-on-use/ 


\section{REVIEWS}

Jennifer Bowering Delisle. The Newfoundland Diaspora: Mapping the Literature of Outmigration. Waterloo, Ont.: Wilfrid Laurier University Press, 2013. ISBN 978-1-55458-894-7

In The Newfoundland Diaspora, Jennifer Bowering Delisle examines the profound cultural, social, and emotional impacts of outmigration, a phenomenon that has become so endemic to Newfoundland that Lisa Moore has described the tension between "the need to leave" and "the desire to stay" as "perhaps the most defining characteristic of life" in this province (quoted in Delisle, 27). As Delisle's compelling study illustrates, outmigration has also shaped a great deal of Newfoundland's recent literature.

Although Delisle explores the beginnings of the "migrant literary tradition" (3) in the poetry of E.J. Pratt and the Atlantic Guardian essays of writers such as Arthur Scammell, her book focuses primarily on contemporary writers, including Donna Morrissey, Carl Leggo, David French, Wayne Johnston, Helen Buss/Margaret Clarke, and David Macfarlane. Her comparative, multigenre study is divided into five sections, exploring diasporic subjectivity, affective responses to outmigration, authenticity, Newfoundland nationalism, and ethnicity.

In her discussion of the affective responses of Morrissey and Leggo, Delisle provides a long overdue reappraisal of the value of the nostalgic and sentimental tradition of Newfoundland literature, a tradition that has been much maligned by a succession of Newfoundland scholars since Patrick O'Flaherty's pivotal study, The Rock Observed (1979). Place philosophers like Edward Casey have long argued that in a world of increasing mobility, we often speak of leaving home as though it "were just a matter of exchanging positions in a geographical board game having no significant stakes" (Casey, xii). But as Delisle suggests, 
sentimental novels like Morrissey's Sylvanus Now and What They Wanted are valuable precisely because they reveal that, in Newfoundland, the "stakes" of leaving are high. For "diasporic Newfoundlanders," as Delisle calls them, leaving home often disrupts a sense of identity and belonging and results in a deep sense of loss and alienation, which is exacerbated by the negative cultural stereotypes Newfoundlanders encounter on the mainland. Moreover, as Delisle observes, the "sense of mourning" prompted by outmigration is felt not just by those who have left the island, but also among "Newfoundland society as a collective" (47).

Similarly, in her examination of Carl Leggo's poetry, Delisle makes the timely case that we cannot paint all nostalgic representations with the same brush. For most critics, nostalgia is dangerous because it conceals class and economic differences, presents a distorted and "inauthentic" image of Newfoundland, often for tourists, and stymies future development (see Overton; O'Flaherty). Building on the work of recent nostalgia theorists such as Roberta Rubenstein, Svetlana Boym, Andrew Ritivoi, and John Su, Delisle contends that what she calls "experiential nostalgia" serves a number of "productive" functions: it provides diasporic subjects with a "coping" mechanism, it allows them to preserve their identity $(52,62)$, and it enables them to connect their individual experiences with a larger collective through the "transmission of affect" (Brennan, quoted in Delisle, 62). For Delisle, experiential nostalgia may be "mediated by familiar codes" or "stereotypes," but it is distinguished from tourist nostalgia by the short distance between the "nostalgic subject and the memory object" (52). Although her desire to distinguish between different types of nostalgia is laudable, Delisle's reliance on experience raises important questions about subsequent generations of diasporic writers. Namely, how short a distance is adequate for nostalgia to be deemed "experiential"? And can readers who have not lived what writers are describing appreciate experiential nostalgia, or does it become, upon transmission to the inexperienced, a form of ersatz nostalgia, to borrow Arun Appadurai's term?

In addition, Delisle's recourse to experience risks re-inscribing the very notions of authenticity that she so diligently problematizes in subsequent chapters on Pratt and Johnston, where she reveals the tendency of critics to project "their own anxieties about regional and national identity" onto diasporic writers (83). In one of the strongest sections of the book, Delisle argues that critical studies of Pratt's poetry reflect more about the Zeitgeist of cultural nationalism in Canada and Newfoundland in the 1970s, when many of the studies were written, than they do about the time period in which Pratt was 


\section{Reviews}

writing. So whereas Pratt's poetry was embraced by Canadian nationalists, who were eager to "appropriate Newfoundland into Canadian space" (83), it was rejected by Newfoundland nationalists, who felt that Pratt's representations of the outports, regarded as the "essence" of an identity threatened by Canadian assimilation, were scarce at best and inauthentic at worst (75). As Delisle observes, the problem is that both of these interpretations read Pratt's work "anachronistically" (78) and "perpetuat[e] a marginal, homogeneous vision of Newfoundland culture" (83).

Likewise, Delisle astutely notes that debates over the geographical authenticity of Johnston's The Colony of Unrequited Dreams attempt to enforce a kind of "conservative" regionalism (75), where regional works are judged and valued on the basis of mimesis, and where diasporic writers are unfairly charged with the responsibility of serving as "native informant[s]" (Spivak, quoted in Delisle, 93). As Delisle maintains, however, Johnston's postmodern technique deliberately resists being confined to conservative regionalist readings and in so doing challenges "the very notion[s] of authenticity and the restrictive cultural stereotypes" such readings attempt to assert (86).

Delisle's discussion of French's Mercer plays and Johnston's Baltimore's Mansion and The Colony of Unrequited Dreams shows how diasporic subjectivity is complicated by feelings of Newfoundland nationalism in a province where nationhood remains an unfulfilled promise. Through their art, Delisle suggests, both authors preserve "the idea of Newfoundland as an imagined community," and thereby "prevent ... the erasure of Newfoundland as a distinct identity" (142). What Delisle fails to acknowledge, though, is that the land-based nationalism she says Johnston espouses has its roots in nineteenth-century nationalist movements, which, as historian Sean Cadigan observes, began the tradition of Newfoundland governments "pa[ying] scant attention to marine resources" in favour of landward industrialization, a tradition that contributed to the collapse of the fisheries and thereby exacerbated the problem of outmigration it hoped to solve (Cadigan, 290).

Despite the book's strengths, Delisle's study raises unsettling questions about the appropriateness of using terms such as "ethnic" and "diasporic" to describe Newfoundlanders and the experience of Newfoundland outmigration. In the same vein as Jewish diasporic scholars Daniel and Jonathan Boyarin, Delisle argues against a critical approach that defines diaspora according to various pre-defined criteria, so that certain groups "are more 'diasporic' than others" (quoted in Delisle, 10). Employing the work of Lily Cho, Delisle contends that we must understand diaspora as a "condition of subjectivity" (quoted 
in Delisle, 10). Yet we must ask whether it is appropriate and useful to discuss all migrations using the same terminology, given that, as Susan Spearey asserts, "[m]igration, clearly, can be seen as either imposed, an act of flight, or voluntary and strategic, an act of will" (Spearey, 53). It may well be that, in Newfoundland, social and economic pressures make labour migration seem imperative, but such migrations - unlike those imposed by the violence of the Middle Passage-are nevertheless "an act of will." So whether we can speak of displaced Newfoundlanders as having a "diasporic subjectivity" remains a matter of some debate. So, too, does Delisle's move in the final section of her study, where she argues that Buss/Clarke's and Macfarlane's second-generation memoirs represent a kind of postmodern ethnicity. Such a move risks homogenizing a people whose experiences - as Delisle's study so thoroughly details - are as complex and as varied as their responses to outmigration.

Caitlin Charman

Memorial University of Newfoundland

\section{WORKS CITED}

Appadurai, Arjun. Modernity at Large. Minneapolis: University of Minnesota Press, 1996.

Cadigan, Sean T. Newfoundland and Labrador: A History. Toronto: University of Toronto Press, 2009.

Casey, Edward. Getting Back into Place: Towards a Renewed Understanding of the Place World. Bloomington: Indiana University Press, 1993.

O'Flaherty, Patrick. The Rock Observed: Studies in the Literature of Newfoundland. Toronto: University of Toronto Press, 1979.

Overton, James. Making a World of Difference: Essays on Tourism, Culture and Development in Newfoundland. St. John's: ISER Books, 1996.

Spearey, Susan. "Mapping and Masking: The Migrant Experience in Michael Ondaatje's In the Skin of a Lion," Journal of Commonwealth Literature 29, 2 (1994): 45-60. 